\title{
FLORIDA CHRISTMAS BIRD COUNT
}

\section{by J. F. ROY*}

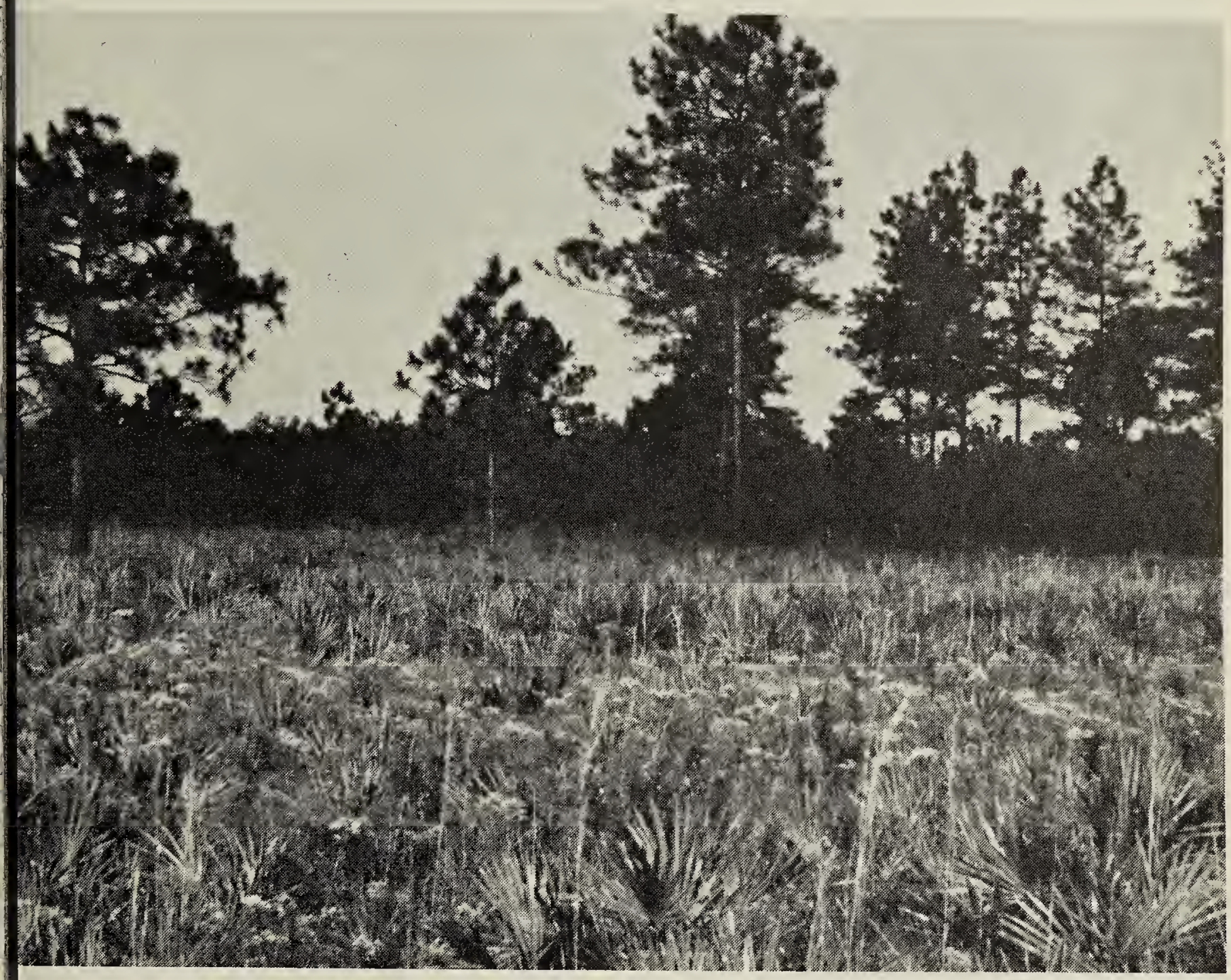

Imetto-pine pasture, Tampa, Florida.

Frank Roy

153 species and over 70,000 inviduals in a single day? Having to op for extra drinks at noon because e blazing sun had raised the mercury just under $80^{\circ}$ ? Pileated Woodckers, Purple Finches, Barred Owls, d Great Horned Owls within a uple miles of Common Gallinules, hingas, White Ibis and a Limpkin? here? When? It was Tampa, Florida, ecember 28, 1974. The occasion: impa's annual Christmas Bird bunt.

702 Sommerfeld Avenue, iskatoon, Saskatchewan.
When I knew I might be in Florida in time for one of the later Christmas Counts, I checked Audubon Society's American Birds for the names of the organizers of last year's Florida counts. Bill Courser, a biologist with the Southwest Florida Water Management District, had compiled the Tampa count. I telephoned him as soon as $I$ arrived in that large city on the Gulf of Mexico, mid-way down the west coast of the state.

"Will you let an ignorant Northerner who doesn't know the difference between an immature Green Heron and a Least Bittern join you on Saturday?" 


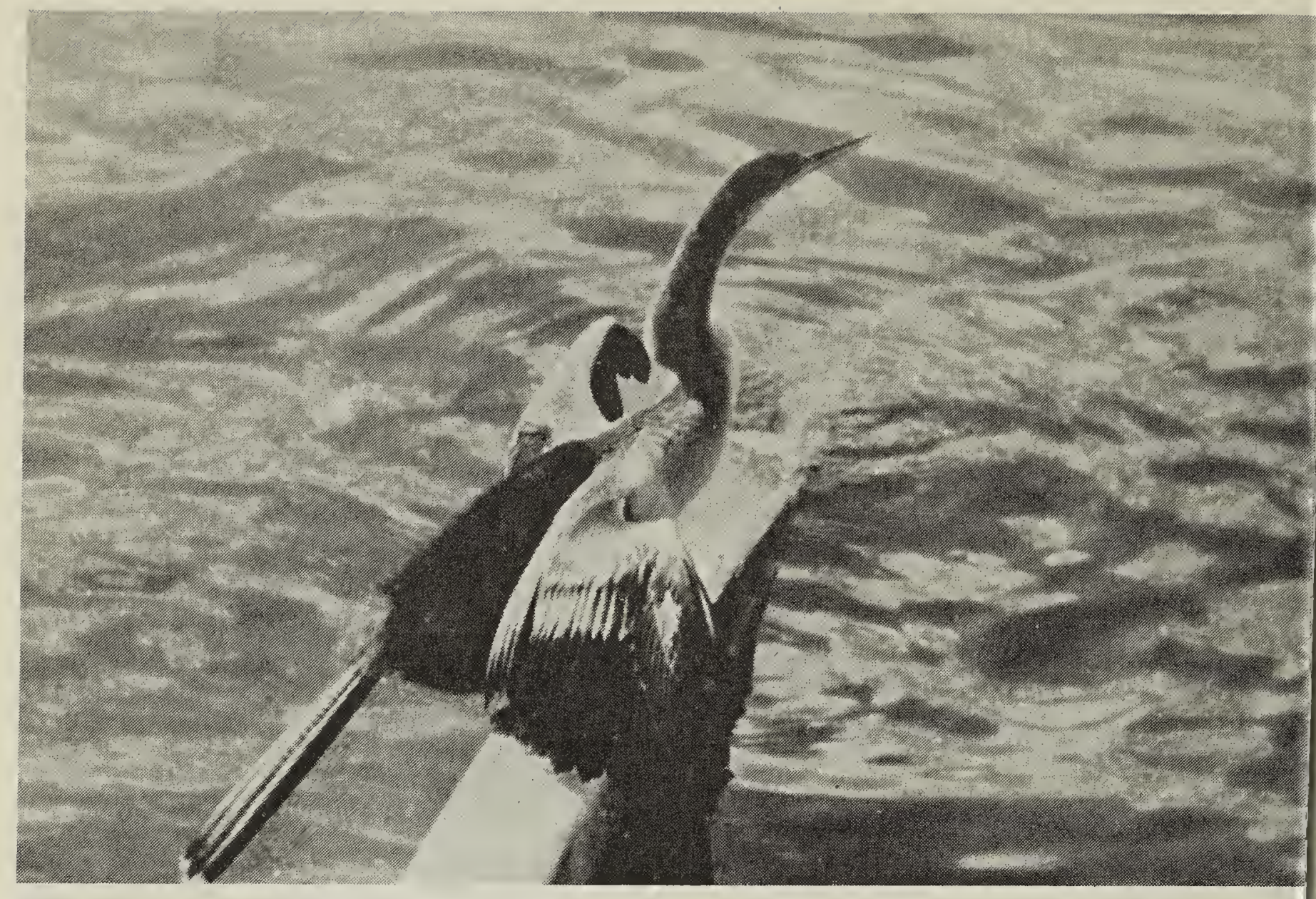

Anhinga, Cypress Gardens, Florida.

Frank R

"Welcome on board," he said. Meet us at Morrison's Cafeteria at Fletcher and 30th at 6:30 a.m. We want to be in the field before sunrise at seven. I'll be out counting owls at 4:00 a.m., but I'll join you there."

I made a dry-run out to the rendezvouz spot the day before the count 17 miles across the city from our hotel. A wise decision, it turned out. Unusually warm weather had resulted in several dense morning fogs in recent days. December 28 , produced a real pea-souper, rolling in from the Gulf of Mexico. I left the hotel at 5:30 in case I should lose my way in the fog. Luck was with me. I parked at Morrison's and waited.

The city was still quiet. A Killdeer called; a flock of Boat-tailed Grackles flew over. Precisely at 6:30 a well-used Dodge station wagon rolled onto the lot. Four men stepped out into the mist: Bill Courser, Ron Mumme, Dale De Wild, and Ed Caldwell were ready to introduce me to the winter birds of the Tampa region.
Our assignment was to canvass th northeast section of the count area. $\mathrm{H}$ would scour palmetto and pir pastures, deciduous forest, roadside the marsh on the campus of th University of South Florida, an aba doned airport, and the weedy fiel adjacent to Busch Gardens.

Visibility was only fair until abo 10 a.m. when the hot sun burned the fog. Having been granted pe mission to walk the woods at pastures of a large ranch just north the city, we broke into two groups. B Courser, Dale De Wild and I head into the forest: the other fellows plored the banks of the Hillsborou River. Contrary to my expectatio the forest floor was open - the rest I suppose, of dense summer folia Now most of the trees were leafless oak, ash and maple. Several species evergreen oak and palm provid splashes of green. At times it was underfoot, and I learned to skirt boggy places. 
The woods, dripping wet in the fog, vere alive with sounds, several of hem alien to my ears. On all sides we heard the raucous cries of Blue Jays and Red-shouldered Hawks, both common in central Florida. Great Horned and Barred Owls hooted in he distance. I soon learned to ecognize the nasal calls of the Blueray Gnatcatcher, a relative of our kinglets. Yellow-rumped Warblers litted everywhere in the branches verhead, and I identified my first White-eyed Vireos. Solitary Vireos, farolina Wrens (what a beautiful ong), Tufted Titmice, Cardinals, humerous silent winter Robins, Goldinches, Yellow-shafted Flickers and Yellow-bellied Sapsuckers moved hrough and above the trees. Three immature Purple Finches alighted on a ree just above our heads. A rarity in Florida, they were an unexpected adlition to the count. My familiarity vith them in Saskatchewan helped us o confirm their identification.

Moving out to more open areas, doted with palmetto, bushes and scatered slash pines, we were scolded by humerous House Wrens, more furtive han when we see them in Saskathewan. Here, too, we saw numbers of Mockingbirds (surely one of the most ommon birds in Florida), Mourning Doves, Loggerhead Shrikes, Tree swallows and Palm Warblers. After nid-morning, Turkey Vultures began o sweep in great circles overhead.

Using sticks to beat the grass and palmetto plants, we sought to flush the ground sparrows that winter in the egion. Incidentally, the sticks also erve a second purpose: they can alert he hiker to rattlesnakes, still fairly fommon in this region. Grass sparrow dentification is difficult enough in Canada when the birds help by singing ind perching on tall weeks; here, luring the Florida winter, it is nearly mpossible. Uttering only a single chirp as they fly up at your feet to drop again into dense grass or palmetto perhaps 25 yards ahead, they must be flushed time after time until a view is obtained of breast, or tail, or median and eyebrow lines. Here, and in brushy fields later in the afternoon, we identified Vesper Sparrows, Savannahs (the most numerous winter sparrow), Swamp Sparrows, and the scarce and local Bachman's Sparrow. We also raised a number of Eastern Meadowlarks, but many needed no coaxing. They flew to convenient posts or bushes to sing their characteristic tsee-you, tsee-ear, a far cry from the melodious cascades of their Western cousins.

Leaving the pasture-land, we skirted fence-lines on either side of the highway. Noon was approaching, and as at home on the May-Day Count, it was becoming harder to add new species. Bill, on the other side, identified a Grasshopper Sparrow. On my side of
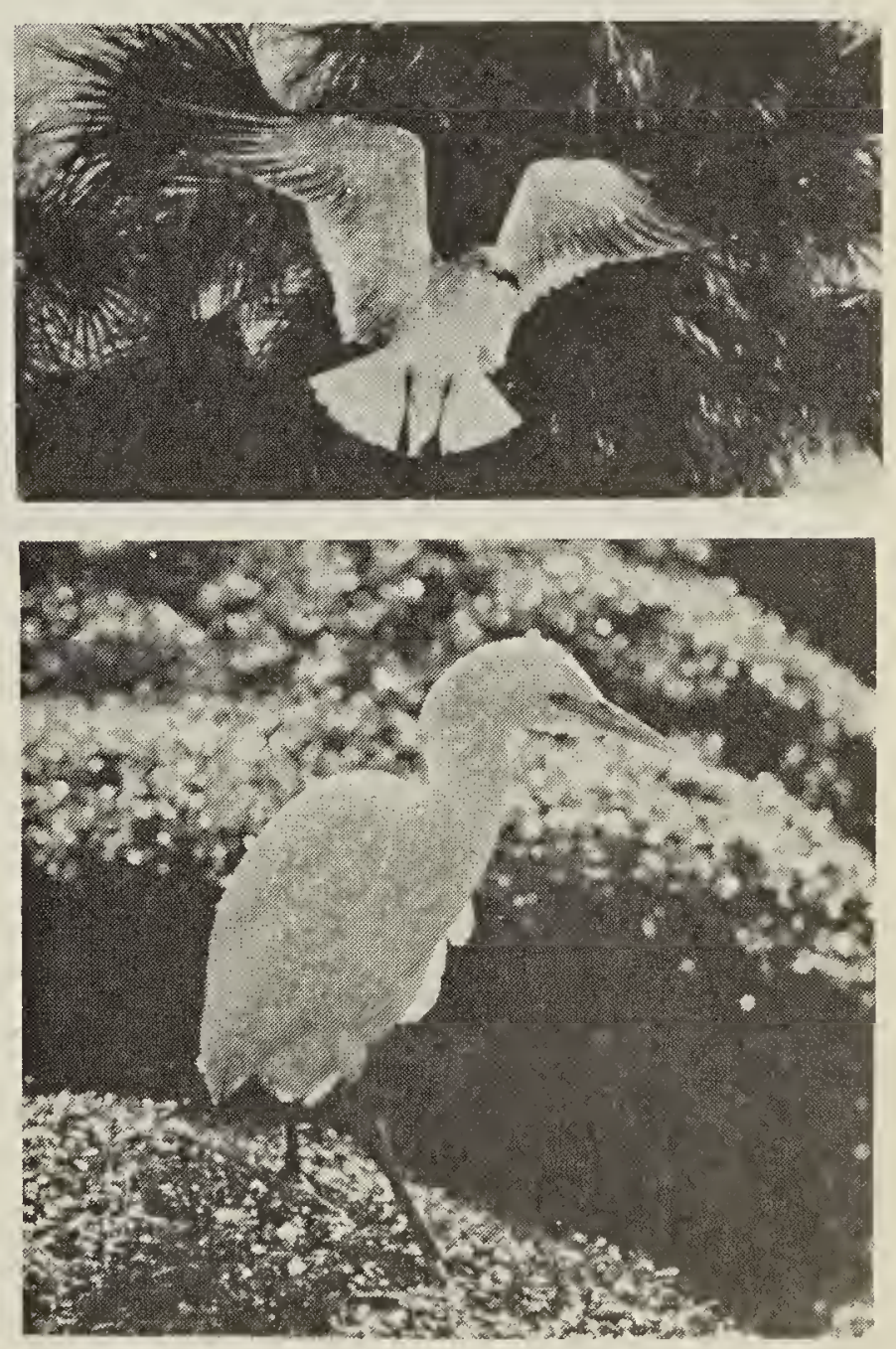

Laughing Gull, Clearwater, Florida.

Cattle Egret, Busch Gardens, Florida. 
the road I flushed a Bobwhite, and added a Sharp-shinned Hawk and a Black-and-White Warbler.

As we joined forces with the rest of the fellows, Ron Mumme, a veteran birdman still in his early 20 's, asked me if I wanted to see a Limpkin. Another lifer for me, it stood in the shade on the banks of Cypress Creek. Restricted in range in the United States to Georgia and the Florida peninsula, it is a handsome, speckled, brown and white water bird related to the cranes and rails. Although we visited only a couple of ponds and marshes, we saw a number of other water birds during the day: Pied-billed Grebes, Great Blue Herons, Green Herons, Cattle Egrets (common all over Florida, even in the cities), Great Egrets, a flock of six White Ibis, Wood Ducks, Ring-necked and Ruddy Ducks, over 300 American Coots, Common Gallinules and several Snipe.

After lunch - a period of sporadic munching extending from 10 a.m. to 1 p.m. as it does everywhere on bird counts - we visited the 10-acre marsh on the University of South Florida campus, a beautiful spot, lush with cattails. How long it can be preserved is anybody's guess; the pressures to drain marshland are even greater in Florida than they are in Saskatchewan. The several hundred ducks which had been in the marsh the day before had taken wing, leaving behind a few Ring-necks and Ruddies and rafts of Coots and Gallinules.

We spent the latu afternoon in what is known as the Tampa Industrial Park, a partially developed district with weedy fields and sparsely-grassed areas north and east of Busch Gardens, a popular preserve for exotic animals and birds. Here Bill Courser, an authority on the Florida race of the Burrowing Owl, showed us no fewer than nine birds. Imitating their call with ease, he soon brought these curious little owls out of their burrows. We even spotted sever within the confines of Busch Garden perfectly at home with the zebras, gnt and African antelope which were crol ping the grass at their very doorsteps. asked Bill what kind of burrows the owls had taken over. "In the sands Florida," he replied, "they use th holes of the gopher turtle or they d their own." No ground squirrels badgers in Florida, I concluded.

The fields produced few ne species, but more sparrows, dozens Savannahs, in particula Meadowlarks, Ground Doves, Bol whites, Boat-tailed and Comme Grackles, Cowbirds, and Palm War lers.

The sun was setting when we retu ned to Morrison's Cafeteria and n parked car. Our group had tallied species -70 short of the total cou for the region, but a satisfactory nun ber for the habitat to which Bill hi assigned us. In addition to the speci already mentioned, I had sec Laughing Gulls, Fish Crows an Yellow-throated Warblers, none which, as far as I can determine, ha yet been recorded in Saskatchewa Rarities in Tampa on a Christm Count included the Black-necked Sti Eastern Kingbird, Great Cresto Flycatcher, Blackburnian Warble Northern Waterthrush and Purp Finch.

I learned more about Florida bi life and winter plumages in that o day than I would have done in a mon of birding by myself. While Saskator birders uncovered a record 42 speci on Boxing Day, a migrant Saskatonia 2 days later, helped in a count whi surpassed in number of species ma of the May-Day Counts at home. I c fered my thanks to Bill Courser at his friends, and suggested they mig like to join us sometime on Boxi Day when the temperature was -20 They made no promises! 